\title{
Dagligliv på Nørrevold
}

- hvad udgravninger og genstande kan berette

\section{Af Lennart S. Madsen}

Nørrevold, oprindelig Arnsholm, ved Arrild, er et af de smukkest bevarede voldsteder fra middelalderen. Udgravninger i årene 1974-80 gør det muligt at rekonstruere anlæggets omrids temmelig nøje. Men hvor meget ved vi om dagliglivet på stormandsgården? Dette spørgsmål prøver museumsinspektør Lennart S. Madsen her at besvare gennem en fremlæggelse af dele af det store fundmateriale. Samtidig diskuteres, hvor meget eller lidt - vi egentlig kan slutte ud fra de bevarede genstande.

\section{Et besøg på Arnsholm i 1365}

Abbed Olav var ved at være træt. Hele dagen havde han redet rundt til Løgum Klosters gårde $\mathrm{i}$ området mellem klosteret og Roost for at tilse bedrifterne og tale med de lægbrødre, der drev nogle af gărdene. Nu var det sidst på eftermiddagen, og han var på vej til »det nye« Arnsholm ved Arrild, hvor han skulle mødes med borgherren, Valdemar Sappi. Og det ville næppe blive et helt behageligt møde. De skulle diskutere, hvem der havde retten over det område, hvor Valdemar Sappis gamle borg, der også havde heddet Arnsholm, havde ligget, indtil kong Valdemar ødelagde den i foråret 1351. Sappi dyrkede fortsat området, skønt alle vidste, at det hørte under klosteret i Løgum, og kun havde været i Sappis besiddelse, fordi han en tid havde været klosterets foged. Olav var sikker på, at den mægtige mand ville holde hårdt på sit, selv om man nu skrev 1365, og det var længe siden Valdemar Sappi havde været klosterfoged.'

Da han langsomt kom ridende over bakken, der fra Roost strakte sig ud i Fiskbæk-lavningen, fik han øje på Arnsholm. Den lå - hævet over Fiskbækkens vandspejl - midt ude i dalen, og så stor og uindtagelig ud, som den lå der badet $\mathrm{i}$ eftermiddagssolen. Olav holdt sin hest an, og kiggede nærmere på Valdemar Sappis hovedborg. ${ }^{2}$

Borgens bygninger lå på tre sandbanker, der på alle sider var omgivet af vand. Bankerne var blevet forhøjet med tørv, der var sikret mod udskridning ved hjælp af nedbankede pæle. Mod syd og vest var voldstedet omgivet af en smal ydervold. Den svage østenvind fik røgen fra ildstederne på gårdens østlige forborg til at hylle selve borgbankens kvadratiske munkestenstårn i en tågedis. Men alligevel var det tårnet, der sås tydeligst her fra bakketoppen. Det var den eneste murstensbygning, såvidt Olav kunne se, og tårnet var markant 


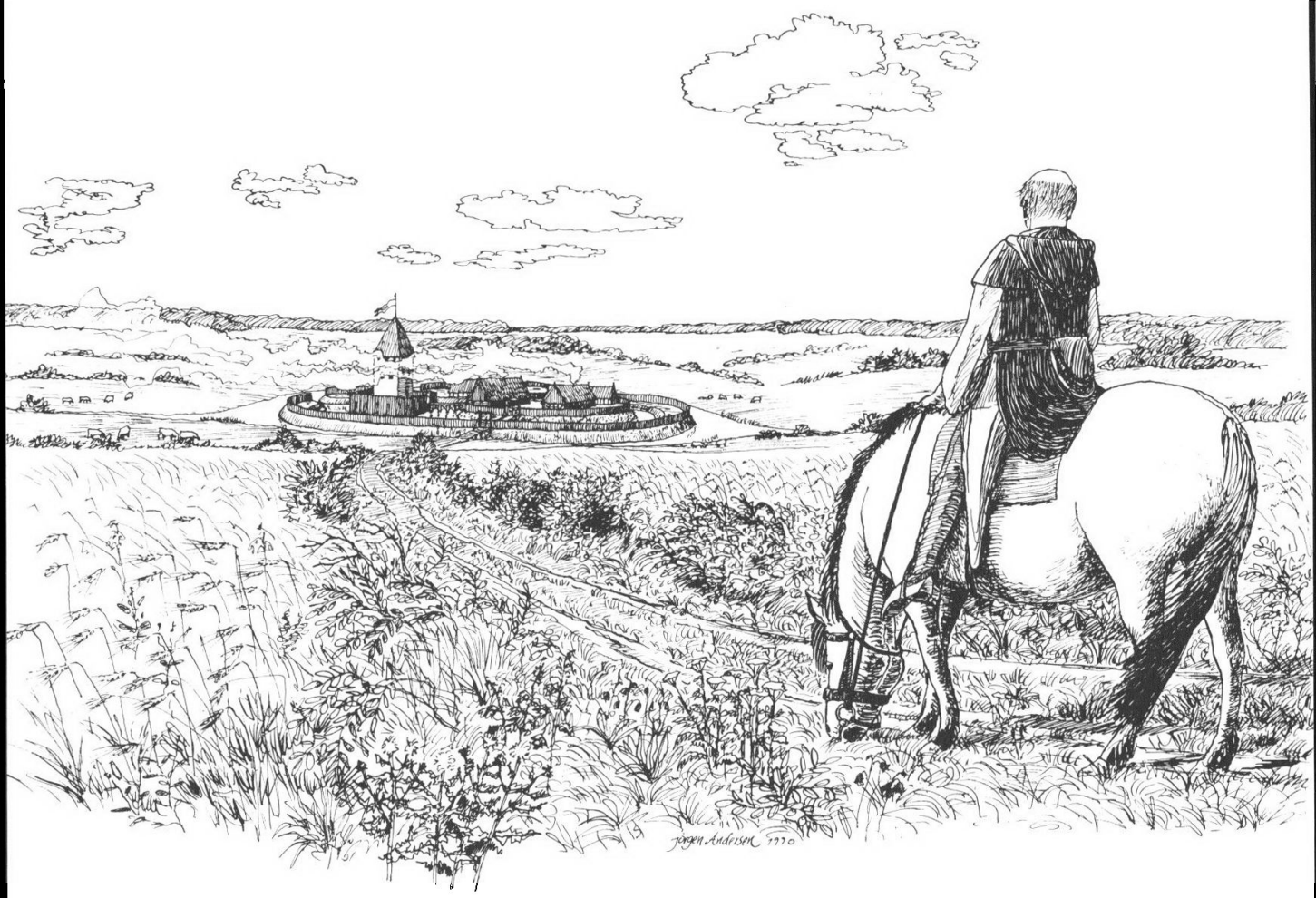

"Olav holdt sin hest an, og kiggede narmere på Valdemar Sappis hovedborg".

I tegneren Jørgen Andersens streg antydes Nørrevold, som den på baggrund af udgravningerne må formodes at have set ud. Det er kun på afstand, og kun med en tegning, at det er muligt at give et visuelt indtryk af borgen på en sădan måde, at der er et rimeligt belag for de detaljer, som fremgår. Selv efter de omfattende udgravninger er der mange uafklarede sporgsmal tilbage, og derfor kan der ikke fremlagges en detaljeret gengivelse af borgen set på ncert hold.

højere end alle andre bygninger på borgen. Rundt om borgbanken løb et palisadehegn, og den var forbundet med den østlige forborg med en bro.

På denne forborg lå der - i modsætning til borgbanken - adskillige bygninger. De var alle opført i bindingsværk med lerklinede vægge, med undtagelse af et større hus, der lå ud til den del af voldgraven, der adskilte forborgen fra tårnet. Denne bygning var opført $\mathrm{i}$ bul, kraftige vandretliggende egeplanker, og Olav tænkte, at det måtte være her borgherren boede, når han ind imellem havde stunder til at opholde sig på Arnsholm. Og det var vel også her, de skulle mødes i aften. Længst mod nord kunne Olav se endnu en stor banke med nogle bindingsværksbygninger, men det var på den østlige forborg, at der var liv. Der steg røg op fra flere af husene, og han kunne se mange mennesker 
optaget af deres forskellige gøremål. Man måtte være ved at forberede aftensmåltidet. Olavs mave knurrede.

Det var til denne del af borgen, at broen over Fiskbækken gik. Men først måtte han passere de bevæbnede vagtposter på ydervolden, og de havde allerede fået øje på ham. Abbeden sporede sin hest og red ned ad bakken mod Arnsholm.

\section{Udgravningernes vidnesbyrd}

Når vi i dag har mulighed for at danne os et indtryk af, hvordan Nørrevold så ud i 1365, skyldes det de udgravninger, der i 1974-1980 fandt sted i et samarbejde mellem Nationalmuseet og Haderslev Museum under ledelse af museumsinspektør Hans Stiesdahl. ${ }^{3}$ Voldstedet er et af de største og bedst bevarede i Sønderjylland, og samtidig et af de få, hvorom der findes skriftlige vidnesbyrd. Borgen, der i samtiden kaldtes Arnsholm, opførtes af Valdemar Sappi omkring 1351 som afløser for hans ældre borg af samme navn (sandsynligvis det nuværende voldsted Søndervold, sydvest for Roost). ${ }^{4}$ Valdemar Sappi var, specielt i $1360^{\circ}$ erne, en af rigets mægtigste mænd og hørte efter 1351 til $\mathrm{i}$ inderkredsen omkring Valdemar Atterdag. Han var søn af hertug Erik Valdemarsen (1312-1325) og halvbror til hertug Valdemar Eriksen (1325-1364) og til kong Valdemars dronning, Helvig. Til hans embeder hørte bl.a. stallerembedet i Frisland og embedet som høvedsmand på Riberhus. I 1360-61 blev han slået til ridder. Han nævnes sidste gang i 1367 og er sandsynligvis omkommet under krigen 1368-69. I hvert fald forsvinder både han og Arnsholm ud af kilderne på dette tidspunkt. Efterfølgende kilder antyder, at arvingerne har ligget $\mathrm{i}$ hård strid om hans gods. Borgen er sandsynligvis blevet opgivet/ ødelagt, da holstenerne erobrede Jylland i 1368.

Borgen på voldstedet har altså, hvis man kan fæste lid til de skriftlige kilder, kun været i funktion i ca. 20 år, og er derfor velegnet til at give et øjebliksbillede af, hvordan der så ud på en stormandsgård i midten af 1300-tallet. Langt de fleste arkæologiske undersøgelser finder sted på lokaliteter, der har været benyttet af mennesker over en lang årrække, og hvor både bygninger og genstande kan være vanskelige at sætte ind $i$ en snæver tidsmæssig ramme. Dette er ikke tilfældet på Nørrevold. Her må bygninger, palisader, broer og lignende være opført over en kort årrække og har sandsynligvis fungeret hele borgens levetid. Valdemar Sappi har set dem, han har boet her, og hans børn har leget mellem de bygninger, der fandtes spor efter. Det er altså muligt at digte en begivenhed, som den om abbed Olavs besøg på Arnsholm, der - selv om den ikke er en historisk begivenhed - godt kunne være foregået ved Arrild 
i 1365, og sætte den ind i nogle konkrete fysiske rammer, som man på baggrund af udgravningerne på Nørrevold ved må have eksisteret dette år. Tydeligvis supplerer historie og arkæologi her hinanden på bedste vis.

Desværre levner udgravningsresultaterne os ikke mulighed for at følge abbed Olav længere end til midt på skråningen ned mod Nørrevold. Jo tættere han kommer på borgen, desto mere tåget og uklart bliver det billede, arkæologien kan fremmane af, hvad abbeden egentlig så. For det første er Nørrevold langt fra totaludgravet, så mange detaljer om borgens udseende ligger endnu gemt under det beskyttende græstæppe. For det andet har generationer af græssende køer med deres klove trampet svage bygningsspor og lignende bort. Det vil derfor, selv med vore dages avancerede udgravningsmetoder, være umuligt at genskabe et fuldstændigt billede af, hvad abbed Olav så, da han red over broen og ind på borgpladsen. Der er da også naturlige grænser for, hvad arkæologien kan fortælle på baggrund af spor $\mathrm{i}$ jorden. I heldigste fald er det muligt at erkende, hvilken funktion en bygning eller et anlæg kan have haft. Båseskillerum afslører stalden, en bevaret esse smedien, og - som det er tilfældet på Nørrevold - vil resterne af et bulhus med bevaret teglstensgulv i fine mønstre antyde, at her lå borgens hovedbygning. ${ }^{5}$ Men hvordan vægge, døre og tag så ud, eller hvad de enkelte rum i en bygning blev brugt til, fortæller sporene i jorden kun meget sjældent.

Alt afhængig af hvor meget der er bevaret, er det altså muligt at antyde nogle kulisser på baggrund af de arkæologiske udgravningers resultater. Men skal man gøre disse kulisser levende, befolke dem med mennesker og inventar, kan arkæologien ikke bidrage med noget bedre end de genstande, der mere eller mindre tilfældigt er bevaret for eftertiden. Genstandene kan give os en fornemmelse af, hvad abbed Olav så på Nørrevold, og hvad han foretog sig, mens han var der. De er på mange måder det nærmeste, arkæologien kan komme menneskets konkrete, fysiske hverdag. Anlægsspor i jorden er kun sjældent mere end sporadiske rester af, hvad der engang var, og de er hyppigt åbne for tolkninger. Genstandene er derimod, skønt ofte ituslåede og omdannede til ukendelighed, de samme ting, som datidens mennesker har haft i handerne, og dermed en direkte forbindelse til deres hverdag.

Hvis man derfor skal følge abbeden på hans videre færd denne sommerdag i 1365, må man ty til de genstande, der blev fremgravet over de seks somre, udgravningskampagnen på Nørrevold varede. Haderslev Museum modtog i 1988 de sidste ting retur fra konservering, således at genstandsmaterialet på i alt 558 numre, fordelt på ca. 2000 genstande og 1200 stk. keramik, i dag kun afventer den endelige videnskabelige bearbejdning for at kunne udnyttes $i$ fuldt omfang."

Det er imidlertid vigtigt at gøre sig klart, at disse mange genstande kun er 


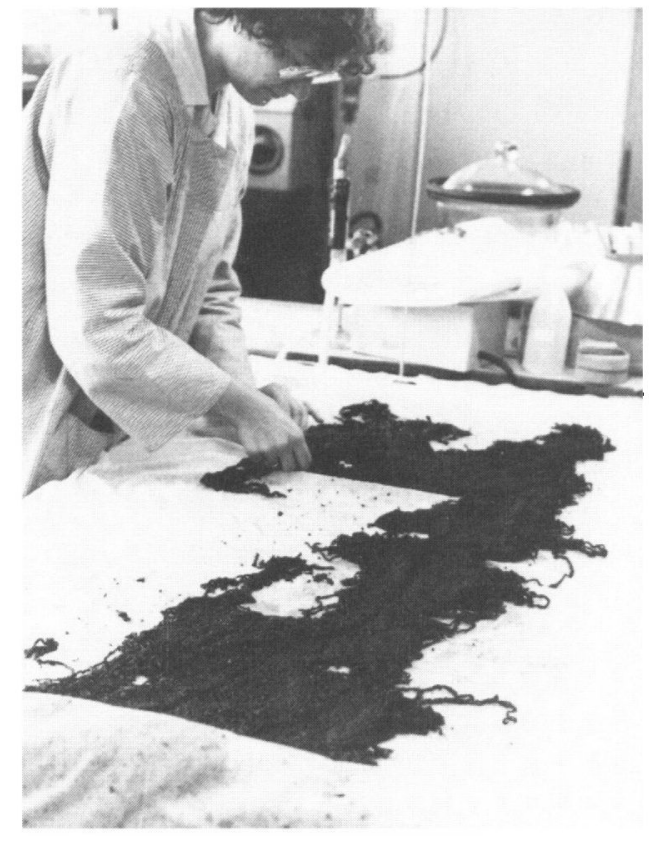

I 1983 konserveredes to, indtil $3 \mathrm{~m}$ lange stykker vavet stof, fundet som en sammenrullet bylt $i$ voldgraven. Behandlingen, hvortil der medgik 22 arhejdstimer, blev foretaget på Haderslev Museums davarende konserveringsafdeling af konserveringstekniker Risë Taylor, og hestod $i$ gentagne vaskninger af det skrohelige materiale. Hertil anvendtes bl.a. kvillay'a bark sabe, et gammelt middel til vaskning af uld, samt almindelig sabe iblandet carboxymethylcellulose, et kemisk middel der binder snavs, sà dette ikke under vaskningen satter sig på stoffet igen. Foto: Haderslev Museum.

et helt tilfældigt udpluk af de mange, mange ting, der har fundet anvendelse på Nørrevold igennem 20 år. For det første er borgen ikke totalundersøgt, så meget ligger stadig derude, og for det andet er det umuligt at vide, hvad der $I K K E$ er blevet tabt eller bortkastet. De fundne genstande fortæller kun meget sjældent noget om, hvad der ellers har været. Desuden spiller bevaringsforholdene en stor rolle for, hvad der findes, og hvad der efter få år er gået til. Netop i den sammenhæng er materialet fra Nørrevold fremragende, idet voldgravens konstante fugtighed har bevaret genstande af læder, træ og stof, der ellers normalt sjældent findes bevaret.

Det efterfølgende vil forme sig som en kort præsentation af genstandsmaterialet fordelt efter disses funktion.

\section{De fundne genstande}

\section{Våben}

Nørrevold er opbygget som et forsvarsanlæg, så ikke overraskende har en del af de fundne genstande en militær funktion. Helt dominerende inden for gruppen af våben er armbrostboltene, dvs. de forholdsvis tunge jernspidser, 
der sad monteret på armbrøstens korte træpile. Der er fundet i alt 66 armbrøstbolte, hvoraf en del endnu sad på den bevarede træpil. De fandtes spredt over alle udgravningsfelter, hvilket muligvis kan tages til indtægt for, at borgen på et tidspunkt (1368?) har været udsat for et angreb. Armbrosten dukkede op i Danmark i 1200-tallet, og blev hurtigt et meget almindeligt våben, ikke blot i krigsøjemed, men også til jagt. ${ }^{7}$ Specielle jagtpile er da også repræsenteret $\mathrm{i}$ materialet, bl.a. den såkaldte »klumppil«, en pil med et tykt, cylinderformet hoved beregnet til jagt på mindre pelsdyr. Da pilen ikke var spids, ødelagde man ikke pelsen.

I den tidlige middelalder bestod krigernes rustning af små, sammenflettede metalringe, som en almindelig pil kun vanskeligt kunne gennemtrænge. Men da armbrøsten havde en betydelig større gennemslagskraft end buen, måtte man i løbet af 1200-årene udvikle en ny rustningsform, pladerustningen. Den fik igennem århundrederne utallige former, men i 1300-tallet bestod den i princippet af en mængde små jernplader, der med nitter eller tråd var hæftet på en kjortel af skind eller stof. ${ }^{8}$ Der er på Nørrevold fremdraget godt 20 sådanne jernplader, de fleste dog så korroderede, at deres oprindelige form er vanskelig at bestemme. Enkelte synes dog at stamme fra en brigantine, en rustning hvor pladerne sad hæftet til kjortelen i horisontale rækker.

Af øvrige våben skal her nævnes to spydspidser, et fragment af et sværd og parèrpladen fra en rondel-daggert. Daggerten, eller dolken vandt afgørende indpas i krigsudrustningen i 1300-tallet. Med det kraftige, smalle blad kunne man let finde en revne $i$ den ellers tætte pladerustning, og tildele en falden modstander nådestødet. I middelalderen kaldes disse dolke da også hyppigt "misericordia«, barmhjertighed.

\section{Heste- og rideudrustning}

Hesten spillede en stor rolle $\mathrm{i}$ middelaldermenneskets hverdag, og de har sikkert været talrige på Nørrevold. Der er da også fundet en del genstande med relation til heste og ridning. ${ }^{9}$ Ikke overraskende er der en del hestesko bevaret. Skikken at besko heste kommer til Danmark omkring 1100, og som med så meget andet ændrer disse også form igennem tiden. Skoene fra Nørrevold er alle af en type, der kommer frem omkring 1300, nemlig den såkaldte "højdragtssko" (tidligere kaldet spansk sko). Højdragtsskoen er forsynet med kraftige hager og er specielt karakteristisk ved, at grenenes spidser er opadbuede, således at det må have været nødvendigt at skære én til halvanden $\mathrm{cm}$ af hestehovens bageste hjørner for at kunne montere skoen ordentligt. ${ }^{10}$ Enkelte af skoene er forsynet med en eller to riller, hvori sømhullerne er placeret.

Andet rideudstyr er kun fundet i enkelte eksemplarer, heriblandt den ene halvdel af et massivt trensebid, en todelt knebel $i$ hestens mund fastgjort i en 


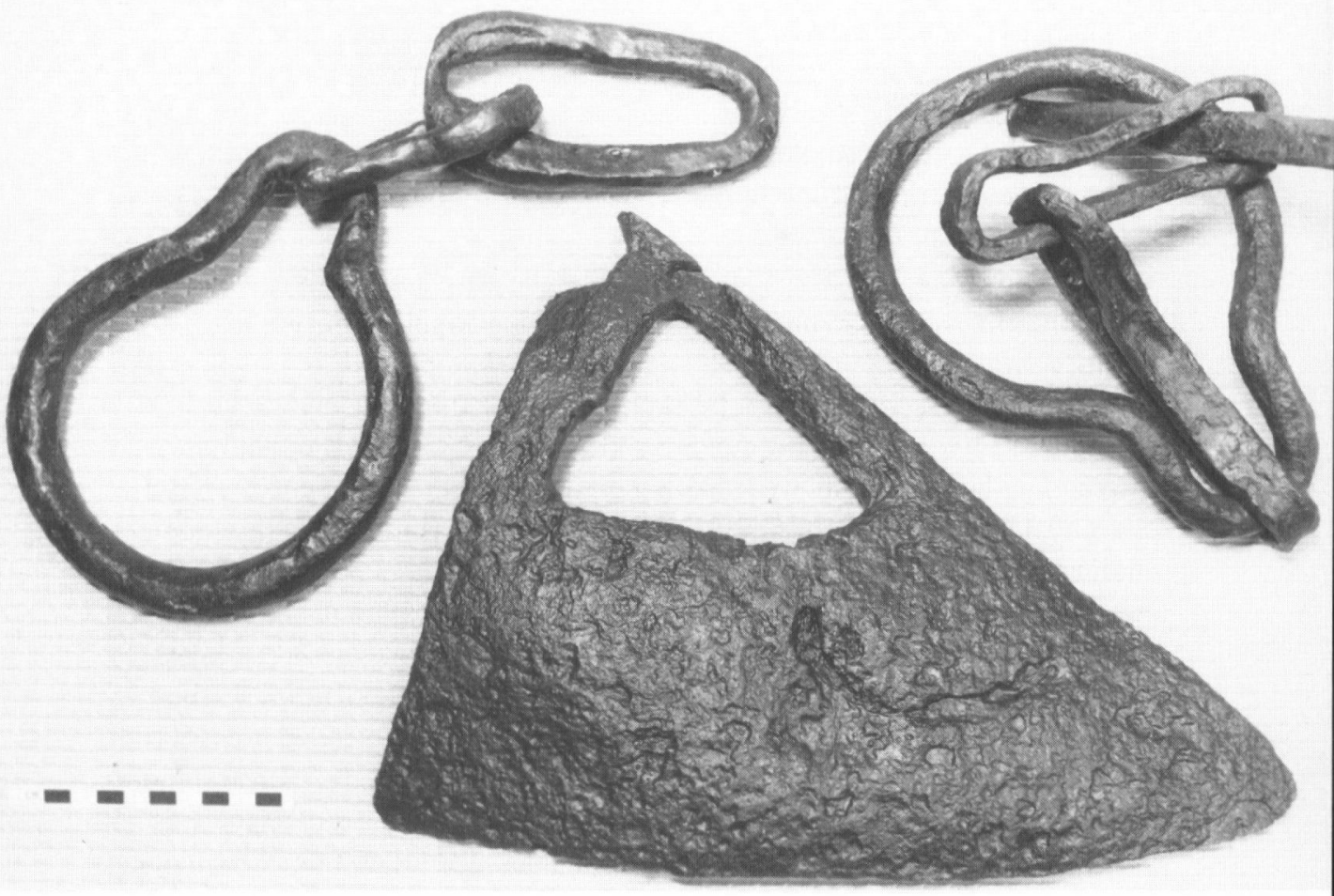

Plovskar og plovkader fundet pa den ostlige forhorg i henholdsvis 1977 og 1980. Plovskaret har siddet monteret vandret med den hvalvede side opad, som pä billedet, idet man skal forestille sig ploven korende fra venstre mod hajre. Skaret lä ovenpả den korte del af den naturligt krumvoksede sule, hvis lange del foroven var fastgjort i plovens as. Med en tap (bemark brudfladen foroven, til venstre) var skaret fastgjort til et hul i sulen, horet ind netop hvor denne krummede. Foto: Hans Peter Jergensen. Haderslev Museum.

ring på hver side af mulen. Heri fastgjordes tøjlen. Denne type bid benyttedes hele middelalderen og anvendes såmænd stadig. Fem hjulsporer er repræsenteret i materialet. Denne sporetype bliver næsten enerådende i 1300-tallet, og skønt hjulet med de mange spidse pigge umiddelbart ser farlig ud, blev det faktisk indført for at beskytte hesten. Ved en utilsigtet berøring med hestens side vil hjulet blot dreje rundt $\mathbf{i}$ stedet for at flænge hesten. Enestående er fundet af to stykker læder, der med al sandsynlighed stammer fra en saddel. Det drejer sig om to læderstykker, hvis udskæring antyder, at de har fungeret som beklædning på sadlens træsæde. 
Varktoj og redskaber

Nørrevold har, på trods af dens forsvarsmæssige indretning, til daglig fungeret som en stor gård, med alt hvad det indebærer af arbejde og de dertil nødvendige redskaber. Af størst betydning var vel landbruget, men landbrugsredskaber er som sædvanlig dårligt repræsenteret i fundmaterialet set i forhold til, hvor stor en betydning de må have spillet $\mathrm{i}$ dagligdagen. Betydningsfuld er dog fundet af et plovskar og plovkader, begge overordentlig sjældne i danske fund. De stammer begge fra en muldfjælsplov, og manglen på fund fra sådanne plove er desto mere beklagelig, idet meget tyder på, at netop introduktionen af denne plovtype kom til at spille en meget stor rolle for landbrugsproduktionens udvikling og landbrugets organisering på overgangen fra oldtid til middelalder."

Det trekantede, svagt buede plovskær er, på trods af et større "sparehul«, meget tungt. Det har krævet et solidt skær at pløje den græsbundne jord ved Arrild. Det har sandsynligvis siddet monteret $i$ hjulploven ved en tap, der dog nu mangler. ${ }^{12}$ De to plovkæder ${ }^{13}$ består af to store jernringe, hvori der sidder monteret en kraftig jernkæde med delvist fladtrykte led. Plovkæden har skullet fastholde hjulstellet til selve plovstangen, åsen, på en sådan måde, at plovens hældning og dermed plovfurens dybde kunne justeres.

Fund af landbrugsredskaber inkluderer også en spade, en greh, en segl og en stigevange (dvs. den ene side af en stige). Fiskbækken og voldgraven omkring borgen har medført, at beboerne var i daglig kontakt med vandet. Dette afspejler sig bl.a. i et par hådshager og en enkelt åre, samt fundet af en klump flettet snor, der kan stamme fra et net eller en ruse.

Smeden og tømreren må have været betydningsfulde personer på en stor gård som Nørrevold, og deres værktøj og produkter er da også til stede i fundmaterialet. Smeden kendes gennem fund af smedeslagger, dvs. kalotformede slagger, der bliver resultatet af den rensning af jernet, smeden foretager i essen. ${ }^{14}$ Derimod er der ikke fundet eksempler på hans værktøj. De produkter, der var resultatet af smedens arbejde, er til gengald rigt repræsenteret, idet mange af de fundne jerngenstande må forudsættes fremstillet af borgens egen smed. Udover keramik udgør de mange søm, stabler og gangjern til ophængning af døre og skodder, samt forskellige andre bygningsbeslag langt den største del af fundmaterialet, og er vidnesbyrd om, at på Nørrevold havde smeden rigeligt at bestille.

Træ var, skønt det kun sjældent findes bevaret i udgravninger, nok på mange måder middelalderens vigtigste råmateriale. Teglstenshuse var endnu kun forbeholdt et fåtal, så tomreren var en uundværlig hăndværker ved alt byggeri. Skebor, hammer, økse og båndhøvl er blandt det værktøj, udgravningen har bragt til veje, og mange af tømrerens produkter, nemlig bygningstømmer af 
mange former, ligger endnu bevaret i voldgraven. ${ }^{15}$ Det eneste bygningstømmer, der er medtaget fra udgravningen, er et lille samlingsstykke med fals til et bulhus. Alt andet må være efterladt $\mathrm{i}$ voldgraven.

Både hvad smeden og tomreren angår er det vanskeligt at få fuldstændig klarhed over, hvor omfattende deres produktion og virkeområde har været. Mange af dagligdagens redskaber og husgeråd var fremstillet af jern og træe, og der er næppe nogen tvivl om, at meget af det - her specielt trægenstandene

er fremstillet som husflid. Husflidsarbejde har jo, specielt på landet spillet en stor rolle helt op til vore dage. Men samtidig var 1300-tallets større danske købstæder præget af en meget høj grad af specialisering inden for de enkelte håndværk, således at mange af de genstande, der indgik i hverdagen på Nørrevold, faktisk ikke nødvendigvis skulle fremstilles lokalt. De kunne købes i byen. I hvor høj grad en af rigets mægtigste mænd har benyttet sig af denne mulighed er uvist. Enkelte kilder synes at antyde, at man hos nogle af byernes håndværkerlav har været utilfredse med, at adelen beskæftigede specialiserede håndværkere på sine gårde. ${ }^{16}$ Langt størstedelen af de trægenstande, der har været anvendt på Nørrevold, er sikkert et resultat af husflid eller af tømrerens arbejde. Men er det også tilfældet med de drejede trætallerkener og små stavbægre, der skal omtales nedenfor? Fremstillingen af disse ting var et specialiseret byhåndværk, og det er næppe sandsynligt, at fremstillingen heraf er foregået på Nørrevold, og det samme galder vel mange andre genstande. Noget af det nærmeste man kan komme på, hvilke håndværkere, der var ansat på en stormandsgård $\mathrm{i}$ anden halvdel af 1300-tallet, er regnskabet fra ribebispens fogedgård Brink i Ballum sogn. Det er dateret til 1388-1389, ${ }^{17} \mathrm{og}$ heri opregnes lønudgifterne til gårdens faste personale. Det drejer sig om en bager, en bagersvend, en kældermester, to bødkere, to skræddere, en fodermester og en møller. De øvrige optræder uden tilnavn og har sikkert været medhjælpere, eller de har været væbnede svende. Tømreren nævnes i regnskabet, men har ikke boet på gården.

Bemærkelsesværdig er fraværet af den ellers uundværlige smed, samt tilstedeværelsen af hele to skræddere. På baggrund af hvad der i dag vides, er det kun sikkert at konkludere, at en stor adelig hovedgård har befundet sig $i$ en "grå zone« mellem landsbyernes husflid og selvforsyning og byernes markedsøkonomi og specialiserede håndværk.

\section{Boligudstyr}

Møbler og lignende er ikke bevaret fra Nørrevold, men til boligudstyr kan henregnes to fundgrupper, nemlig låsetoj og lysholdere. Alle bygninger har sandsynligvis været forsynet med lás, og til hver lås hørte en speciel nøgle.

Ejendomsretten var ukrænkelig, og opbrød tyven en lås for at udføre sit 
forehavende, blev straffen fordoblet. ${ }^{18}$ Den middelalderlige lås er da også som oftest meget kompliceret, ja nærmest dirkefri, og der blev konstrueret låse til mange forskellige formål. Netop derfor er det tvivlsomt, om lås og nøgler er et produkt fra borgens smedie. På Nørrevold er der fundet fem nøgler af forskellig størrelse, dog alle af den såkaldte vridlåstype, der jo også kendes $\mathrm{i}$ dag. Desuden er der fundet låsehuset fra en større hængelås.

Havde man først låst sig ind $i$ en bygning, var det ofte nødvendigt med lys, specielt hvor der ikke var lyrehul i taget, åbne glugger eller lignende lyskilder. I sådanne situationer kunne man anvende de såkaldte lysestabler, små koniske piber, hvori der kunne sidde et tællelys, fastsmedet til en, ofte dekorativt snoet spids. Stablen kunne så bankes fast i væggen eller i et bord, hvor man havde brug for lys, alt efter om spidsen stod vandret eller lodret på lysepiben. Der er fundet flere sådanne på Nørrevold, hvoraf en endda er udført sådan, at den kan monteres både lodret og vandret.

\section{Madlavning og husgeråd}

Ikke overraskende består omkring halvdelen af genstandene fra Nørrevold af ting, der på en eller anden måde har tilknytning til madlavning og fortæringen heraf. Det er naturligvis de 1200 stk. keramik, der er medvirkende hertil. Kander, gryder, skåle, fade og lignende i ler spillede en overordentlig stor rolle i middelaldermenneskets hverdag, og da periodens velbrændte keramik er stort set uforgængelig, udgør potteskårene ofte størstedelen af ethvert middelalderligt fundmateriale.

Keramikken er da også hyppigst det, der danner hovedgrundlaget, når arkæologen skal datere et fund. Fremstillingsteknik og mode ændrede sig, både herhjemme og $\mathrm{i}$ udlandet, inden for alle områder, og da keramikken næsten altid fylder mest, er det også her disse ændringer er lettest at registrere og anvende i dateringsøjemed.

En, vel at mærke overfladisk, gennemgang af keramikken fra Nørrevold viser, at den ikke adskiller sig væsentligt fra, hvad man måtte forvente at finde i Jylland i anden halvdel af 1300-tallet. De 1200 skår fordeler sig på ca. 1000 gråbrændte uglaserede skår, 111 rød- og gråbrændte skår med påført glasur og 100 skår af stentøj.

Det er typisk for Jylland, at den gråbrændte keramik dominerer så voldsomt. Ser man på sjællandske voldstedsudgravninger, udgør den glaserede keramik en langt højere procentdel af det samlede keramikfund, i hvert fald i perioden fra ca. $1200-1400 .{ }^{19}$ Der er ikke noget der taler for, at økonomien har spillet nogen rolle, men at det nærmere er tradition, der ligger bag denne forskel i anvendelsen af den glaserede keramik. Den uglaserede, gråbrændte keramik er altså klart den dominerende, og her finder man da også stort set alle 1300- 
tallets karformer repræsenteret: Gryder, potter, skåle, fade og ikke mindst kander. Det meste heraf er udekoreret hverdagskeramik, men enkelte, specielt af kanderne er dog forsynet med dekoration i form af enkle stregornamenter i forskellig form. Helt speciel er nogle enkelte skår med indstemplet dekoration. Den glaserede keramik stammer udelukkende fra to karformer, nemlig udvendigt glaserede kander og indvendigt glaserede bradepander, der anvendtes til at opfange stegefedtet under spidstegning. ${ }^{20}$ Norrevolds datering til 1351-1368 gør, at man i fundmaterialet kan iagttage den glidende overgang der $\mathrm{i}$ anden halvdel af 1300-tallet sker inden for den finere bordkeramik. Den glaserede, og overvejende lokalt fremstillede kande forsvinder langsomt til fordel for det masseproducerede, importerede rhinske stentøj, der næsten udelukkende udfærdigedes som kander, bægre og dunke. Stentøjet dukker op i midten af 1300-tallet, da man i Rhinegnene lærer at styre de høje temperaturer, der er nødvendige for at få leret til at cintre fuldstændigt, og i løbet af et halvt århundrede udkonkurrerer det fuldstændigt den glaserede kande..1 På Nørrevold er denne proces i fuld gang.

Tra har i køkkenet og på bordet, som overalt, været et flittigt benyttet materiale. Bevaringsforholdene på Nørrevold bevirker, at det også er muligt at få dette belyst. Blandt fundene kan nævnes en ca. $80 \mathrm{~cm}$ høj bødkret tønde, der muligvis har været anvendt til opbevaring af fødevarer, et skærebrædt samt adskillige drejede træskåle og -tallerkener. Som tidligere nævnt har der næppe arbejdet en drejer på borgen, idet det er et højt specialiseret håndværk, der må have krævet adgang til et større marked. Det samme gælder for middelalderens foretrukne drikkekar, stavbægeret. Det er fremstillet af små, tynde stave, ofte i en importeret træsort, der med en notrille fastgøres til en cirkulær bund og holdes på plads af en eller flere vidjeflettede bånd på ydersiden. ${ }^{22}$ På Nørrevold er fundet bunden af et stavbæger, og ligesom tallerkenerne må det vare indkøbt f.eks. i Ribe, hvor det vides, at disse håndværkere arbejdede, ${ }^{23}$ og hvortil Valdemar Sappi havde nære forbindelser.

Af køkkeninventaret kan desuden nævnes brudstykker af malmgryder, stenmortere, kværnsten, kobberkedler og muligvis noget så specielt som en paletkniv. $^{24}$

Endelig har fundmaterialet også givet et lille fingerpeg om, hvad man fortærede på Nørrevold, idet nogle af knoglerne har været til identifikation på Zoologisk Museum i København. Der er fundet knogler fra kvæg, får, ged, svin, hest, hare, hund, gråand og kuller. Man har næppe spist hund (og hest?) på Nørrevold, hvorimod de øvrige dyr må være indgået $\mathrm{i}$ husholdningen på forskellig vis. Men det skal bemærkes, at ikke alle knogler er identificerede, og det er uvist, om alle de knogler, der blev fundet under udgravningerne, er bragt med til museet. 


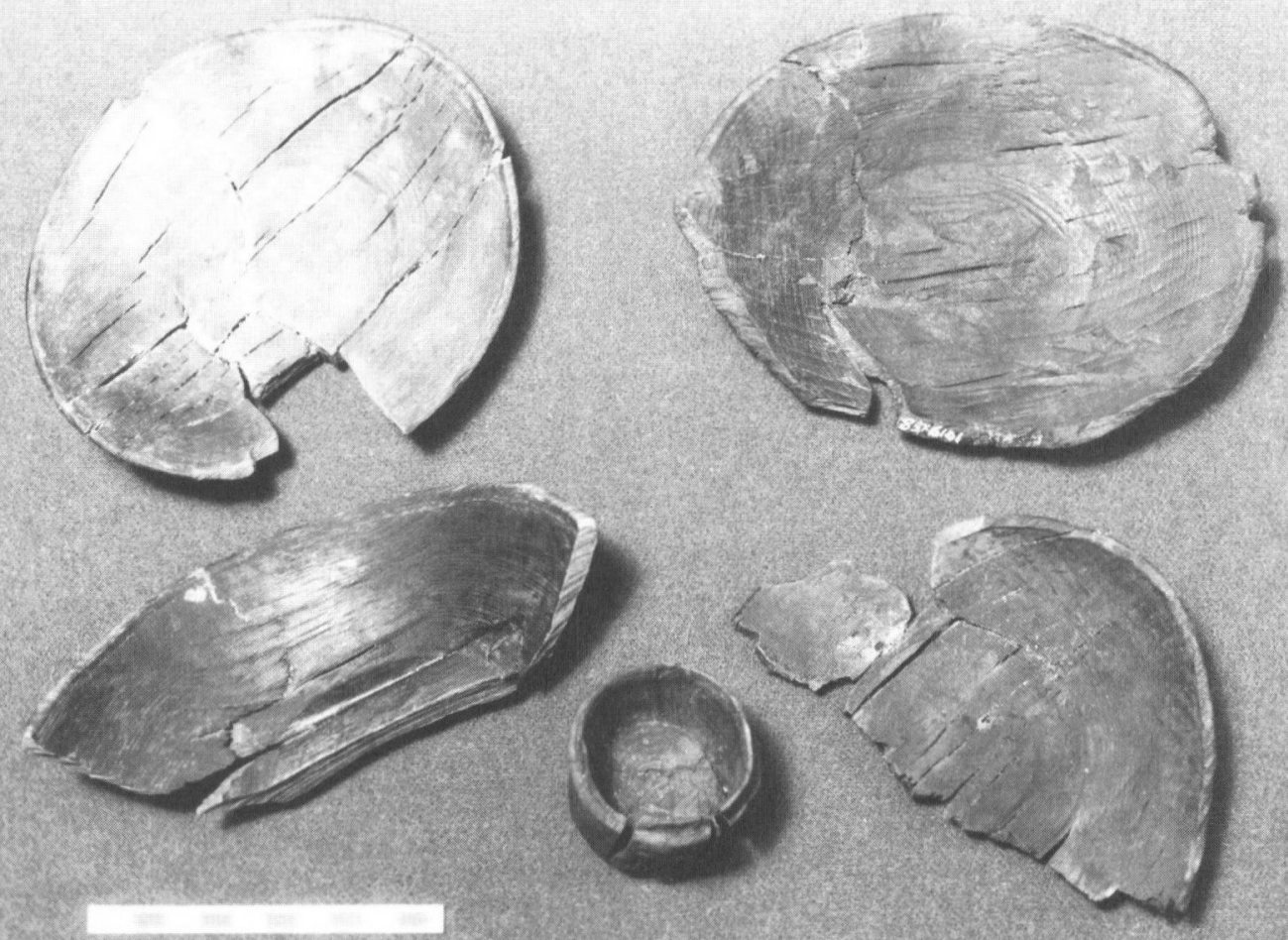

Eksempler pä drejede traskäle samt en lille. $5 \mathrm{~cm}$ hoj krukke, alle fundet $i$ voldgraven.

Kunsten at dreje tra kendes i Danmark allerede fra for Kristi fodsel og havde i middelalderen udviklet sig til et hojt specialiseret händvark, hvis udevere svarverne forstod at udnytte de enkelte trasorters karakteristika optimalt. Til fremstilling af traskale er anvendt forskellige hjemlige trasorter som ask, lon, hirk, el og hog, hvorimod der til spillehrikker, knivskafter og finere genstande hyppigt anvendtes den importerede hukshom eller den sjerldne taks. Foto: Hans Peter Jorgensen. Haderslev Museum.

\section{Klocededragt}

Efter at have set lidt på hvilke genstande, menneskene på Nørrevold omgav sig med, skal deres påklædning afslutningsvis berøres. Dragtstykker findes ikke bevaret i det hele taget er der kun meget få dragtstykker bevaret fra Danmarks middelalder - men derimod dukkede der af voldgravens beskyttende fugt tre stykker vavet stof frem. Det drejer sig om to meget lange stykker på $3,0 \mathrm{og} 2,4 \mathrm{~m}$ 's længde, henholdsvis $53 \mathrm{og} 65 \mathrm{~cm}$ 's bredde. Det tredie stykke er på $30 \times 15 \mathrm{~cm}$. Stoffet er væuet af et mørkt brunt (farven kan dog skyldes de 600 år i voldgraven) håndspundet uldgarn, og er udført i lærredsvævning. 
Stoffet har enkelte steder oprindelige kanter bevaret. Hvad det har skullet anvendes til er uvist, men alene længden taler for, at det drejer sig om vævede stoffer, der skulle anvendes til fremstilling af tøj. Der kan næppe være nogen tvivl om, at dette stof er fremstillet på borgen. Netop fremstilling af tekstiler forblev langt op i tiden et husflidsarbejde.

Kendes der ikke noget til beboernes klædedragt, er vi til gengæld bedre informeret om deres fodtoj. Op imod 300 stykker læder er fremdraget af voldgraven, og heraf stammer langt størstedelen fra sko. ${ }^{25}$ Skomagerhåndværket har vist sig at være et højt specialiseret håndværk, hvor skotyper synes at være nogenlunde ens over hele Nordeuropa, og der er næppe nogen tvivl om, at stort set alt fodtøj er fremstillet af skomagere, og ikke som husflid. ${ }^{26}$ Skoene fra Nørrevold har et meget ensartet præg, idet næsten alle sko er lave, dvs. har en åbning, der sidder lavt på foden, og de synes alle at skulle snøres på foden over en lille trekantet udskæring foran på vristen. Et par af skoene fra voldgraven er desuden smukt dekoreret med udstemplede geometriske mønstre. Speciel er desuden fundet af en træsål med et stykke læder, sandsynligvis en del af en træsko.

\section{Afslutning}

Hvad abbed Olav så, da han bevægede sig rundt på Nørrevold hin dag i 1365, har selvfølgelig ikke været ukendt eller mystisk for ham. Dagliglivet på borgen har næppe formet sig meget anderledes end andre steder, og abbeden har umiddelbart kunnet genkende og forstå baggrunden for alt, hvad der foregik omkring ham. Han har, ved at kaste et enkelt blik ind i smedien, kunnet se hvad smeden var i færd med, og har forstået de arbejdsprocesser, der lå bag; han har kendt retterne, der blev serveret ved aftensmåltidet, og har vel også vidst noget om, hvordan de var blevet tilberedt, og hvilke ingredienser der indgik i dem. Og ikke mindst er alt hvad han så og foretog sig faldet naturligt ind $i$ en sammenhæng. Dagligdagen har hængt sammen og givet mening, og Olav har vel ikke umiddelbart kunnet forestille sig tilværelsen meget anderledes end den var.

Her 625 år senere er det ikke længere muligt at se, og langt mindre at forstå denne sammenhæng. Vi er henvist til de tilfældige brudstykker af datidens virkelighed, der på forskellig vis har overlevet det store spand af år, og skal vi i dag forsøge at beskrive hverdagen i 1365, er det kun muligt ad omveje og med megen usikkerhed.

Det er ikke muligt, blot på baggrund af en arkæologisk undersøgelse af et enkelt voldsted, at komme tæt ind på dagliglivet på en dansk storgård. Dertil 
er sporene $\mathrm{i}$ jorden for svage og det bevarede genstandsmateriale for tilfældigt, hvad gennemgangen af materialet fra Nørrevold med al ønskelig tydelighed viser. Ikke inden for en eneste af grupperne er der bevaret tilstrækkeligt med genstande til, at en tilnærmelsesvis udtømmende beskrivelse af blot et enkelt element af borgens dagligdag kan foretages. Selv med en totaludgravning af borgen må vi erkende, at det aldrig vil være muligt for os at følge med abbed Olav over broen til Nørrevold.

Det er derfor nødvendigt at foretage en omfattende sammenligning mellem mange arkæologiske fund, og igen sammenligne disse med skriftlige udsagn og billedlige fremstillinger, hvis vi i dag skal gøre os håb om at indkredse datidens hverdag med blot nogenlunde sikkerhed. Dagliglivet, som det levedes på voldstedet Nørrevold en sommerdag i 1365, vil vi aldrig kunne forstå, men udgravningen af Nørrevold har, i kraft af de mange bygningsspor og det store genstandsmateriale, føjet en vigtig brik til det puslespil, som den overordnede forståelse for og generelle viden om dagligdagen, som den levedes i Danmark i anden halvdel af 1300-tallet, nødvendigvis må være.

NOTER

1. Historien bygger på oplysninger i følgende to værker: M. Mackeprang: "Løgum Kloster og dets Gods« i: Sjy Årb, 1945.

C. A. Christensen: "Arnsholm og Valdemar Sappi. Et nordslesvigsk drama fra Valdemar Atterdags tid« i Festskrift til Johan Hvidtfeldt, (Tønder, 1978).

2. Arnsholm (Norrevold) er beskrevet på baggrund af oplysninger i: H. Stiesdahl: "Nørrevolde« i Nordslesvigske Museer, bd. 6, 1979. Artiklen er det eneste skriftlige, der foreligger om udgravningerne, og da den fremkom i 1979, har resultaterne fra udgravningen i 1980 ikke kunnet medtages.

3. Voldstedet er beliggende umiddelbart est for Arrild, Arrild sogn, Hviding herred og har sognebeskrivelsesnummer 39, Arrild sogn. Det er fredet, og har fredningsnummer 3906-10.

4. Teorien fremsattes og dokumenteres i C. A. Christensen, 1978. op.cit. ss. 40-42 \& 48-51.

5. H. Stiesdahl, 1979. op.cit. ss. 74-75.

6. Genstandene findes pă Haderslev Museum, registreret under numrene $1019 \times 1-558$. Konservering er foretaget af Haderslev Museums konserveringsafdeling og Nationalmuseets Konserveringsanstalt. Brede. Det bør understreges, at konservering er en langsommelig og ikke mindst dyr proces. Derfor har en del af genstandene ligget ukonserveret så længe, at de få år på museet har været hårdere ved dem, end 600 år $\mathrm{i}$ voldgraven.

Haderslev Museum måtte i 1986 af økonomiske årsager se sig nødsaget til at kassere en del genstande, fortrinsvis mere almindelige genstande af jern, eksempelvis søm. Alle genstande er dog blevet beskrevet og opmålt af forfatteren $i$ lobet af årene 1985-86.

7. Niels-Knud Liebgott: Middelalderens våben. (Nationalmuseet, 1976) ss. 25-28.

8. Bengt Thordeman: Armour from the Battle of Wisby 1361, I. (Stockholm, 1939).

9. Heste- og rideudrustning fra Norrevold er gennemgàet af mag.art. Eskil Arentoft, og materialet er benyttet i dennes specialeafhandling ved Institut for Middelalderarkæologi, Århus Universitet: Rideudstyr og ridning i Danmark gennem tiden ca. 1050-1400, især på baggrund af analyser af jordfundne oldsager. (utrykt, 1986).

10. Ibid, ss. 101-104. 


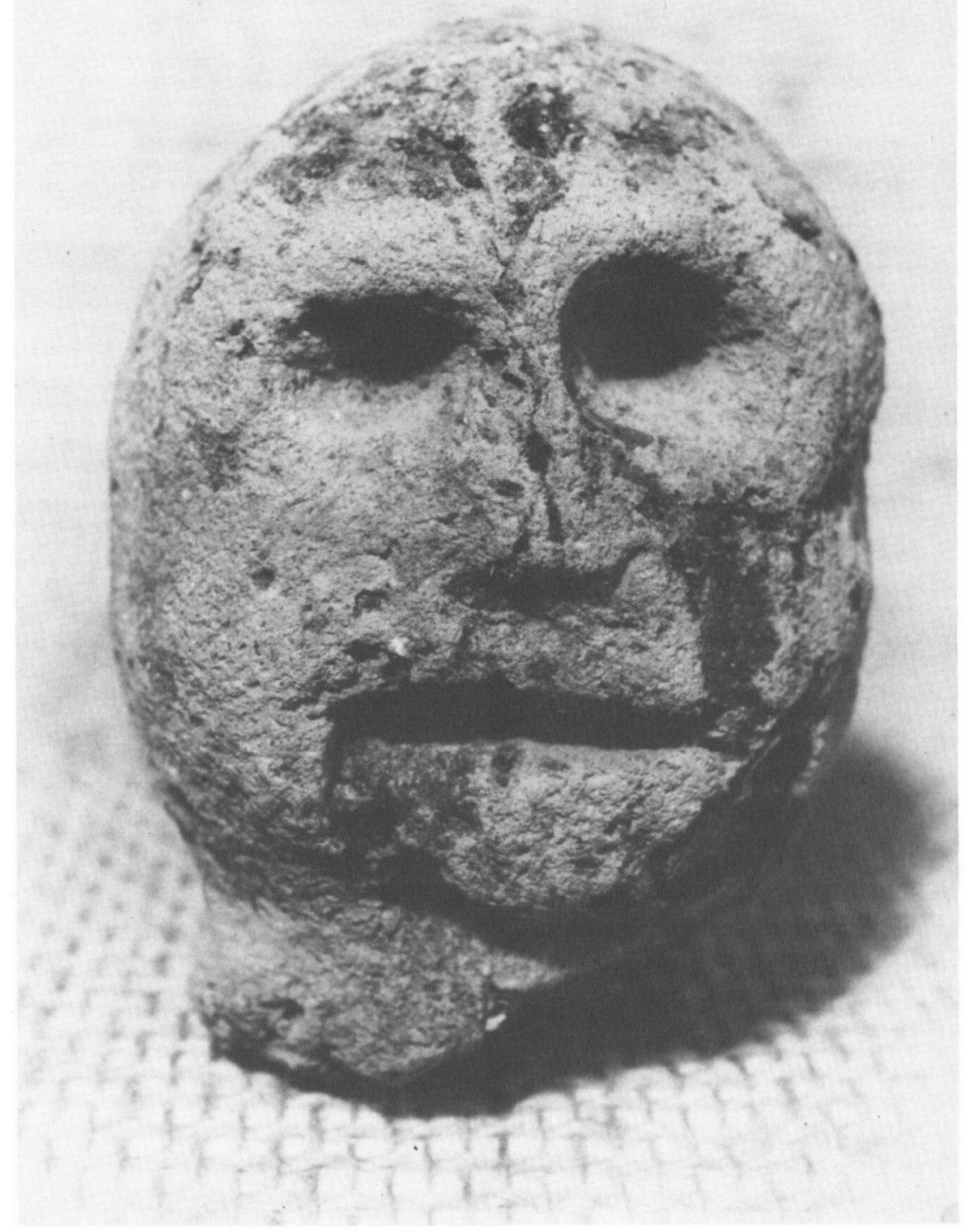

"Arrild-manden". Et godt $8 \mathrm{~cm}$ hojt ansigt $i$ härdtbrondt ler, fundet $i$ udgravningen 1976. Foto: Hans Peter Jorgensen, Haderslev Museum. 
11. Erland Porsmose: "Middelalderen o. 1000-1536« i: Det danske landbrugs historie, bd. 1. (Odense, 1988) ss. 280-286.

12. Plovskæret er undersagt af Grith Lerche, International Secretariat for research on the history of agricultural implements, Nationalmuseet. Jvf. brev fra Grith Lerche i sagen, dateret d. 8/91986.

13. Cand. mag. Ole Vejbæk, Herning har gjort Haderslev Museum opmærksom på plovkæden.

14. Tove Nyholm: "Jernslagger og smedning « i: Hikuin, bd. 14 (Moesgárd, 1988).

15. H. Stiesdahl, 1979, op.cit. s. 75. Niels-Knud Liebgott: Dansk Middelalderarkæologi. (Kbh. 1989) ss. 99100.

16. Grethe Jacobsen: Håndværkets Kulturhistorie, bd. 1. (Kbh., 1982) ss. 42-43.

17. Bjørn Poulsen: "Den middelalderlige storgård. Brinkregnskabet" i: Bondens Penge. Studier i sønderjysk regnskabsmateriale 1400-1650. (Landbohistorisk Selskab, 1990). Forfatteren takkes for tilladelse til at benytte det endnu utrykte manuskript.

18. Niels-Knud Liebgott: Middelalderen, bd. I. Danmarkshistorien, forlaget Sesam (Viborg, 1984) ss. 74-75.

19. Niels-Knud Liebgott, 1989. op.cit. s. 297.

20. Bi Skaarup: Køkkenfunktioner, køkkener og køkkentøj i det senmiddelalderlige Danmark (ca. 1400-ca. 1600). Hovedfagsspeciale i Middelalder-arkæologi, Århus Universitet, 1984. (Udgivet af "Middelalderarkæologisk Nyhedsbrev«, 1989) ss. 24-26 \& 99-101.

21. Niels-Knud Liebgott, 1989. op.cit. ss. 300-302.

22. Mogens Bencard: "Om Ribes rădhus, Skibbroen, en udgravning og et formodet stavbægerværksted « i: Hikuin, bd. 3 (Moesgărd, 1977).

23. Se note 22, samt P. Wagner og M. Bencard: „Drejet træ fra Ribes middelalder« i: Hikuin, bd. 6 (Moesgård, 1980).

24. Om middelalderligt køkkeninventar i arkæologiske fund, se Bi Skaarup, 1984. op.cit. ss. 88-130.

25. Skoene fra Nørrevold er gennemgået af mag.art. Hanne Dahlerup Kock, og materialet er benyttet i dennes speciale-afhandling ved Institut for Middelalderarkæologi, Arhus Universitet: Læderfodtøj fra 1300-tals voldstedet Boringholm. ... (utrykt, 1984). Delvist publiceret i dennes artikel: »Fodtøj af læder og dets datering ca. 1250-1500« i: Hikuin, bd. 14 (Moesgărd, 1988).

26. Hanne Dahlerup Kock: "Hvad fortæller det arkæologiske materiale om skomagerhăndværket fra ca. 1250-ca. 1500« i: Land og by i middelalderen, bd. 4 (Tender, 1986). 